\title{
Effect of Polygonatum odoratum extract on human breast cancer MDA-MB-231 cell proliferation and apoptosis
}

\author{
YU TAI ${ }^{1}$, YI-MING SUN ${ }^{1}$, XUE ZOU $^{1}$, QIONG PAN ${ }^{1}$, YA-DONG LAN ${ }^{2}$, QIANG HUO ${ }^{1}$, \\ JING-WEN ZHU ${ }^{1}$, FEI GUO ${ }^{1}$, CHANG-QUAN ZHENG ${ }^{1}$, CHENG-ZHU WU $^{1}$ and HAO LIU ${ }^{1}$ \\ ${ }^{1}$ Department of Pharmacy, Bengbu Medical College, Bengbu, Anhui 233030; ${ }^{2}$ Department of Surgical Oncology, \\ The First Affiliated Hospital of Bengbu Medical College, Bengbu, Anhui 233004, P.R. China
}

Received March 12, 2015; Accepted April 7, 2016

DOI: $10.3892 /$ etm.2016.3630

\begin{abstract}
Traditional Chinese medicine (TCM) is important in the provision of anti-tumor drugs. Recently, studies have shown that certain types of TCM agents are able to control the growth of tumors, enhance the body's immune function and enhance the therapeutic effect of chemotherapeutic drugs. In women, breast carcinoma is the most common tumor type and the second most common cause of death from cancer. Polygonatum odoratum ( $P$. odoratum) is commonly used in TCM. The aim of the present study was to investigate the effects of $P$. odoratum extract on the proliferation and apoptosis of MDA-MB-231 breast cancer cells. Cell proliferation was assessed using MTT and colony formation assays. In addition, propidium iodide (PI)/Annexin V-FITC staining was used to investigate the apoptosis of MDA-MB-231 cells following treatment with $P$. odoratum extract. The protein expression levels of B-cell lymphoma-2 (Bcl-2) and Bcl-2-associated X protein (Bax) were also detected using western blot analysis, while a JC-1 staining assay was used to assess the mitochondrial membrane potential $(\Delta \Psi \mathrm{m})$. The results of the MTT assay showed that the proliferation and colony formation of MDA-MB-231 cells were inhibited following treatment with the extract. Furthermore, the PI/Annexin-V staining showed that the apoptosis of MDA-MB-231 cells was enhanced by the extract, in a concentration-dependent manner. The extract also lowered the $\Delta \Psi \mathrm{m}$ of MDA-MB-231 cells, upregulated the expression of Bax and inhibited the expression of $\mathrm{Bcl}-2$. In conclusion, these results showed that the $P$. odoratum extract inhibited the proliferation and induced apoptosis of breast cancer MDA-MB-231 cells.
\end{abstract}

Correspondence to: Mr. Hao Liu, Department of Pharmacy, Bengbu Medical College, 2600 Donghai Road, Bengbu, Anhui 233030, P.R. China

E-mail: liuhao6886@foxmail.com

Key words: breast cancer cells, Polygonatum odoratum extract, apoptosis, proliferation, regulatory protein

\section{Introduction}

Breast cancer is one of the most common malignant tumors in females, and poses a serious threat to the physical and mental health of women (1). Breast cancer patients may be affected by physical and psychological problems throughout the whole process of disease diagnosis, treatment and rehabilitation $(2,3)$. Psychological problems may increase the side effects of treatment and affect the patient's quality of life (4). Patients with anxiety, depression, happiness and social support situation will affect the patient's emotional state (5). In women, breast cancer is the most common tumor type by incidence and the second cause of cancer-associated mortality $(6,7)$. Adult height has been demonstrated to be positively correlated with breast cancer risk in various epidemiological studies.(8-11). Statistical data revealed that, among all the malignant tumors reported, breast cancer has the highest incidence in major cities in China, as compared with the rest of China (12-15). In comprehensive breast cancer treatment, based on the present risk-benefit ratio optimization scheme, surgery is first line of comprehensive treatment, in addition to chemotherapy, endocrine therapy, radiation therapy, immune therapy, as well as the use of traditional Chinese medicine (TCM) therapy (16-20). Since the majority of tumors develop resistance to certain drugs, the search for novel antitumor agent is essential. Furthermore, adequately sensitive apoptosis cannot be induced by chemotherapy.

TCM occupies an important position in the development of antitumor drugs. Recent studies have demonstrated that TCM agents are able to control the growth of tumors, enhance the body's immune function and improve the therapeutic effect of chemotherapy drugs (21-23). Polygonatum odoratum ( $P$. odoratum) is a member of the Liliaceae family and is commonly used in TCM (24-26). Previous studies have demonstrated that it increases the level of antibody production, and exerts anti-inflammatory, antiviral and tumor inhibitory effects $(27,28)$. P. odoratum has been used to treat various diseases due to its procoagulant activity (29), anti-hyperglycemic effect $(30,31)$, glucose tolerance improvement (32) and anti-herpes simplex virus-II and apoptosis-inducing activities (33). P. odoratum has been suggested as a potential therapeutic target for the treatment of breast cancer $(34,35)$. 
The aim of the present study was to investigate the effects of $P$. odoratum extract on breast cancer cells. The results of the study may provide novel insights that could assist in the research and development of novel antitumor drugs for the treatment of breast cancer.

\section{Materials and methods}

Cell lines. The MDA-MB-231 breast cancer line (American Type Culture Collection, Manassas, VA, USA) was cultured in the laboratory of the Department of Pharmacy, Bengbu Medical College (Bengbu, China). The cells were cultured in Dulbecco's modified Eagle's medium (DMEM) supplemented with $10 \%$ fetal bovine serum (FBS), $100 \mathrm{U} / \mathrm{ml}$ penicillin and $100 \mu \mathrm{g} / \mathrm{ml}$ streptomycin, and were maintained at $37^{\circ} \mathrm{C}$ with $5 \% \mathrm{CO}_{2}$ in a humidified atmosphere. All the experiments were performed on logarithmically growing cells.

Reagents and antibodies. DMEM, FBS and phosphate-buffered saline (PBS) were purchased from Thermo Fisher Scientific, Inc. (Grand Island, NY, USA). MTT [also known as 3-(4,5-dimethylthiazol-2-yl)-2,5-diphenyltetrazolium bromide] was obtained from Sigma-Aldrich (Castle Hill, Australia). Penicillin and streptomycin were purchased from North China Pharmaceutical Group Corp., (Shijiazhuang, China). Propidium iodide (PI)/Annexin V-FITC was purchased from Sigma-Aldrich (St. Louis, MO, USA). Dimethyl sulfoxide (DMSO) was obtained from Amresco (Solon, OH, USA). Mouse anti-human $\beta$-actin (1:10,000; 66009-1-Ig) polyclonal antibody and rabbit anti-B-cell lymphoma-2 (Bcl-2; 1:1,000; 12789-1-AP) and rabbit anti-Bcl-2-associated X protein (Bax; 1:1,000; 23931-1-AP) polyclonal rabbit anti-human antibodies were purchased from Proteintech Group, Inc. (Rosemont, IL, USA). The mitochondrial membrane potential $(\Delta \Psi \mathrm{m})$ assay kit (C2006), $\mathrm{JC}-1$, bicinchoninic acid protein concentration kit (P0011) and crystal violet stain were purchased from the Beyotime Institute of Biotechnology (Shanghai, China).

Cell proliferation assay. The effect of the $P$. odoratum extract on cell viability was determined using an MTT assay. $P$. odoratum extract was socked in $\mathrm{MeOH}$ for 3 days isolate the filtrate, $\mathrm{MeOH}$ extract was obtained using rotary evaporators. $\mathrm{MeOH}$ extract was dissolved in a isopyknic mixture of EtOAc and $\mathrm{H}_{2} \mathrm{O}$ to obtained the EtOAc layer and the EtOAc extract was isolated using rotary evaporators. Subsequently, EtOAc extract was dissolved in a isopyknic mixture of Hexane and $\mathrm{H}_{2} \mathrm{O}$ to obtain the Hexane layer, and $P$. odoratum extract was subsequently obtained using rotary evaporators. Briefly, the MDA-MB-231 cells were seeded at a density of $1 \times 10^{4}$ cells/well in 96-well plates with $100 \mathrm{ml}$ growth medium. The cells were randomly divided into three groups as follows: Control (no treatment), P. odoratum extract (treatment with extract alone) and blank control (no cells, no treatment, just growth medium) groups. Cells in the $P$. odoratum extract group were then incubated for $24 \mathrm{~h}$ in the presence of $0,0.001,0.01$ or $0.1 \mathrm{mg} / \mathrm{ml} P$. odoratum extract. Next, $15 \mu 1 \mathrm{MTT}(5 \mathrm{mg} / \mathrm{ml})$ was added to the cells, which were incubated in the dark at $37^{\circ} \mathrm{C}$ for $4 \mathrm{~h}$. Subsequent to removal of the MTT solution, the formazan product (crystals) was dissolved in $150 \mu 1$ DMSO by shaking the plates for $10 \mathrm{~min}$. Optical density (OD) was then determined at $490 \mathrm{~nm}$ using a Synergy HT multi-detection microplate reader (BioTek Instruments, Inc., Winooski, VT, USA). The experiments were performed in triplicate, and three parallel samples were measured each time. For calculation of the cell proliferation rate $(\%)$, the following formula was used: OD (experimental group) / OD (control group) x 100.

Colony formation assay. MDA-MB-231 cells in the logarithmic growth period, were seeded at a density of $1 \times 10^{4}$ cells/well in 6-well plates with $2 \mathrm{ml}$ growth medium and incubated for $24 \mathrm{~h}$. Next, the cells were treated with different concentrations of the $P$. odoratum extract $(0,0.02,0.04$ and $0.06 \mathrm{mg} / \mathrm{ml}$ ) for 5 days and maintained at $37^{\circ} \mathrm{C}$ in $5 \% \mathrm{CO}_{2}$ in a humidified atmosphere. The cells were then washed twice with pre-chilled PBS, fixed with paraformaldehyde for $10 \mathrm{~min}$ and stained with $2 \%$ crystal violet for $10 \mathrm{~min}$. Double-distilled water was used to clean the cells until the color of the sample turned transparent, and the cells were then dried at room temperature. Colonies contained 50-150 cells. Colony numbers were counted under a light microscope at a magnification of $\mathrm{x} 40$.

Cell apoptosis assay. A single cell suspension was prepared from MDA-MB-231 cells in the logarithmic growth period and counted using flow cytometry (Accuri C6; BD Biosciences, Franklin Lakes, NJ, USA). Annexin-V FITC/PI staining was performed according to the manufacturer's instructions to assess cellular apoptosis. Cells were seeded in 6-well culture plates $\left(1 \times 10^{4}\right.$ cells/well $)$ for $24 \mathrm{~h}$ prior to the cell apoptosis assay. Next, the cells were incubated with the $P$. odoratum extract at increasing concentrations $(0,0.02$, 0.04 and $0.06 \mathrm{mg} / \mathrm{ml}$ ) for $24 \mathrm{~h}$ and then washed twice with pre-chilled PBS. The cells were resuspended in $500 \mu \mathrm{l}$ binding buffer, following centrifugation at $13,223 \mathrm{x} \mathrm{g}$ for $10 \mathrm{~min}$. Subsequently, $100 \mu \mathrm{l}$ cell suspension was transferred to 5-ml Eppendorf tubes, and $5 \mu \mathrm{l} \mathrm{PI/Annexin} \mathrm{V-FITC} \mathrm{solution}$ was added to each tube and mixed for $15 \min \left(4^{\circ} \mathrm{C}\right.$; dark). Following incubation for $15 \mathrm{~min}$ at $20^{\circ} \mathrm{C}$, the apoptosis rate was determined using an BD Accuri C6 flow cytometer, and the results were analyzed using the flow cytometer software.

Western blot analysis. Stable expression cells were washed three times with cold PBS $(1 \mathrm{ml} /$ well $)$ and digested with trypsin in lysis buffer for $30 \mathrm{~min}$ on ice. The protein concentrations of the cell lysates were detected using a bicinchoninic acid protein concentration kit. The protein sample was mixed with the sample buffer $(2: 1)$ and boiled at $100^{\circ} \mathrm{C}$ with the denaturation buffer for $5 \mathrm{~min}$, and steps were taken to prevent protein degradation. Protein samples from each test group $(30 \mu \mathrm{g})$ were subjected to $10 \%$ sodium dodecyl sulfate-polyacrylamide gel electrophoresis. A condensation protein electrophoresis gel was run at $70 \mathrm{~V}$ for $30 \mathrm{~min}$ and $150 \mathrm{~V}$ for $90 \mathrm{~min}$, and the proteins were transferred onto polyvinylidene fluoride membranes at $50 \mathrm{~V}$ in an ice bath for $90 \mathrm{~min}$. The membrane was then blocked in $5 \%$ skim milk, followed by an overnight incubation at $4{ }^{\circ} \mathrm{C}$ with the primary antibodies against $\beta$-actin. Bcl-2 and Bax (1:1000). 


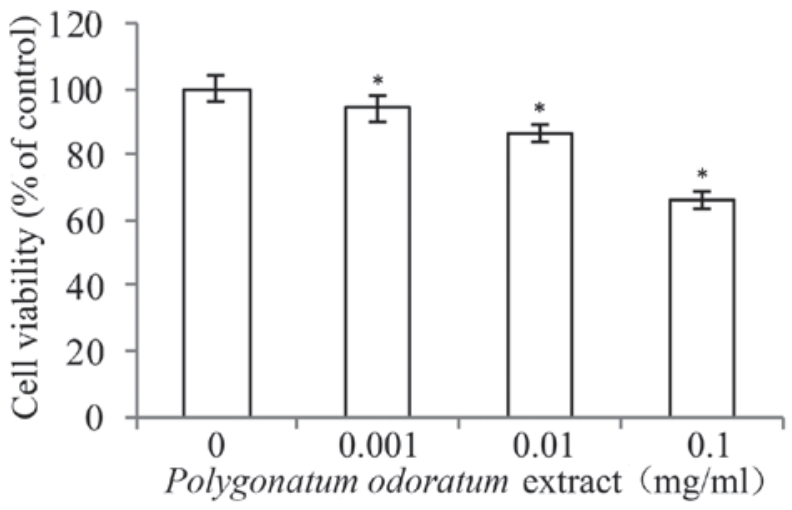

Figure 1. Viability and cell proliferation of MDA-MB-231 breast cancer cells treated with the Polygonatum odoratum extract. The cell viability was inhibited in a concentration-dependent manner. ${ }^{*} \mathrm{P}<0.05$ vs. $0 \mathrm{mg} / \mathrm{ml}$.

Subsequently, the membrane was washed three times with Tris PBS (TPBS) and once with PBS, for 10 min each time. The sample was then labeled with the peroxidase-conjugated rabbit (109525) or mouse (117228) secondary antibodies (1:5,000; ZSGB Bio, Beijing, China) for $2 \mathrm{~h}$ at room temperature on a shaker. Next, the membrane was washed with TPBS, and the bands were visualized using western lightning with enhanced chemiluminescence (EMD Millipore, Billerica, MA, USA). $\beta$-actin was used as the protein control, and the gray values of the protein bands in each group were analyzed using Quantity One 4.6.8.27 gel image analysis software (Bio-Rad Laboratories, Inc., Hercules, CA, USA). The experiments were repeated at least twice to confirm the results.

Measurement of $\Delta \Psi m$. The mitochondrial stability was assessed using a $\Delta \Psi \mathrm{m}$ assay kit with JC-1. MDA-MB-231 cells in the logarithmic growth period were seeded at a density of $2 \times 10^{5}$ cells/well in 12 -well plates with $1 \mathrm{ml}$ growth medium and incubated for $24 \mathrm{~h}$. Next, the cells were treated with $0.1 \mathrm{mg} / \mathrm{ml}$ of the drug. After treatment for $24 \mathrm{~h}$, the cells were washed once with PBS and then incubated with $1 \mathrm{ml} \mathrm{JC}-1$ fluorescent dye for $20 \mathrm{~min}$ in the dark at $37^{\circ} \mathrm{C}$. Subsequently, the cells were washed twice with pre-chilled buffer solution. The $\Delta \Psi \mathrm{m}$ was imaged using a fluorescence microscope (Olympus Corp., Tokyo, Japan) at $550 \mathrm{~nm}$ excitation and $570 \mathrm{~nm}$ emission.

Statistical analysis. All experiments were performed at least in triplicate. Data are presented as the mean \pm standard error of the mean. A double-sided Dunnett's test was used for between-group comparisons. All statistical analyses were performed using the SPSS version 13.0 software (SPSS, Inc., Chicago, IL, USA) and statistically significant differences were indicated by $\mathrm{P}<0.05$.

\section{Results}

Inhibitory effects of $P$. odoratum extract on the viability and proliferation of MDA-MB-231 cells. An MTT assay was performed to determine the effect of $P$. odoratum extract on the proliferation of MDA-MB-231 cells. As shown in
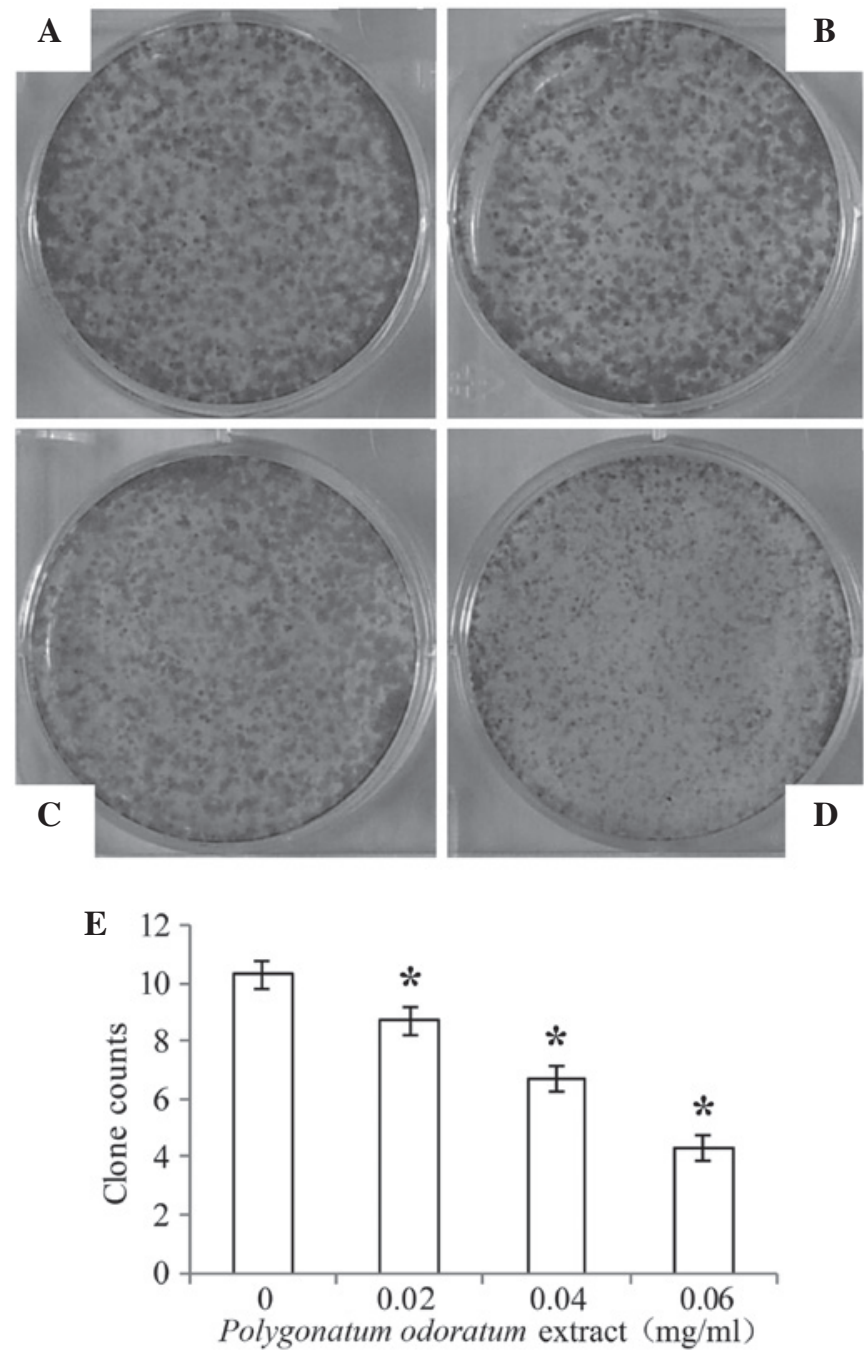

Figure 2. Representative images of MDA-MB-231 breast cancer cell colonies treated with (A) $0 \mathrm{mg} / \mathrm{ml}$ (control), (B) $0.02 \mathrm{mg} / \mathrm{ml}$, (C) $0.04 \mathrm{mg} / \mathrm{ml}$ and (D) $0.06 \mathrm{mg} / \mathrm{ml}$ Polygonatum odoratum extract for 5 days. (E) Quantitifaction of the clone counts demonstrated that treatment with the extract had a significantly inhibitory effect on colony formation in the MDA-MB-231 cells. ${ }^{*} \mathrm{P}<0.05$ vs. $0 \mathrm{mg} / \mathrm{ml}$.

Fig. 1, the viability of MDA-MB-231 cells was altered following 24-h treatment with various concentrations of the P. odoratum extract up to $0.1 \mathrm{mg} / \mathrm{ml}$. The extract inhibited MDA-MB-231 cell proliferation in a dose-dependent manner $(\mathrm{P}<0.05)$.

Furthermore, the colony forming ability of the MDA-MB-231 cells was analyzed using a colony formation assay. As shown in Fig. $2(\mathrm{P}<0.05)$, a significant inhibitory effect was observed in cells treated with increasing concentrations of the $P$. odoratum extract $(0,0.02,0.04$ and $0.06 \mathrm{mg} / \mathrm{ml})$ for 5 days, while low concentration significantly inhibited the cell colony formation. These results suggest that the $P$. odoratum extract has inhibitory effects on breast cancer cell proliferation.

Effect of $P$. odoratum extract on the apoptosis of MDA-MB-231 cells. To determine whether the reduced cell viability was due to apoptosis, PI/Annexin V FITC double staining using the Accuri C6 flow cytometry was conducted. As indicated in Fig. 3 ( $\mathrm{P}<0.05)$, MDA-MB-231 cells treated 

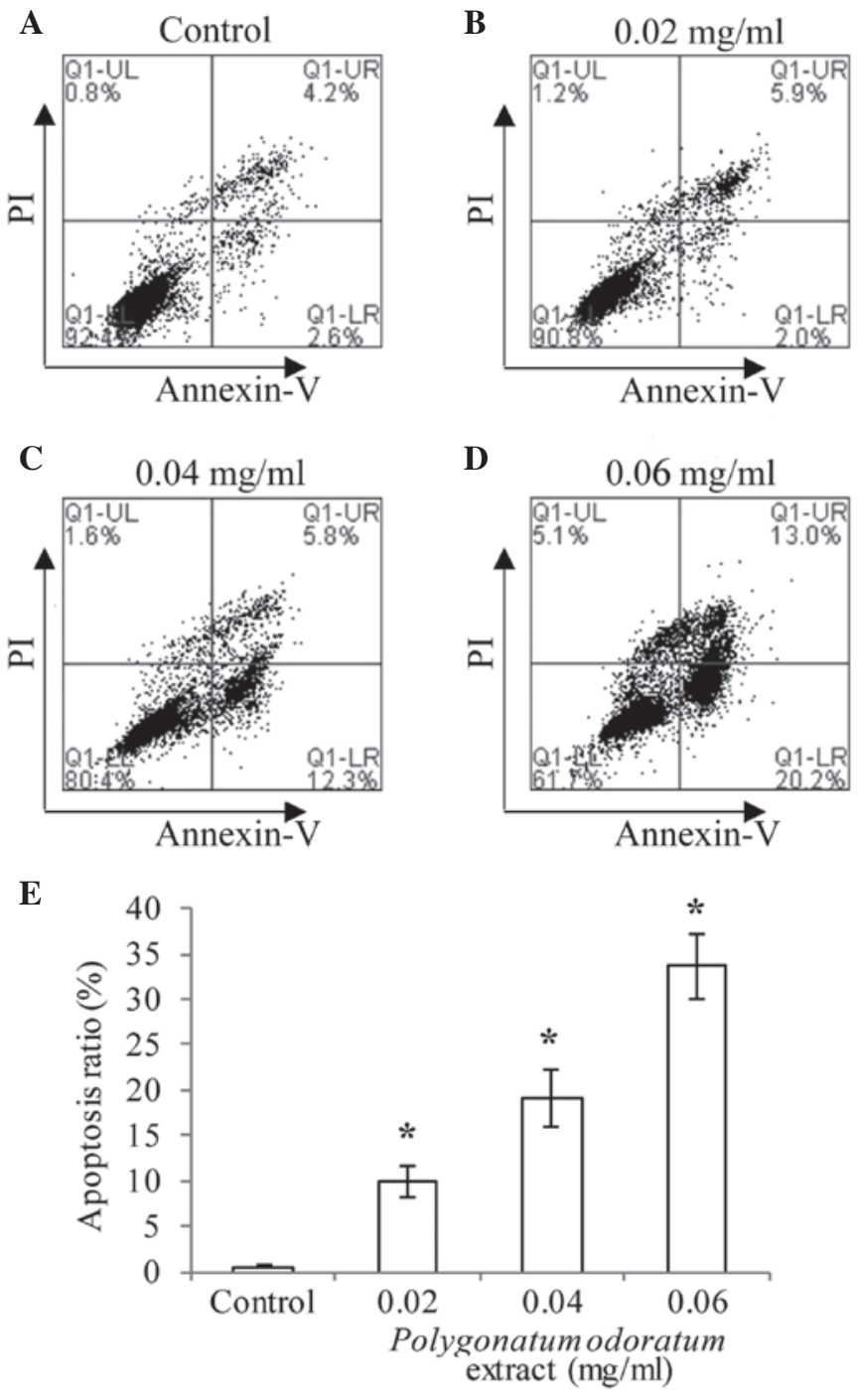

Figure 3. Effect of Polygonatum odoratum extract on apoptosis of MDA-MB-231 breast cancer cells. The cells were (A) untreated (control), or treated Polygonatum odoratum extract at (B) 0.02 , (C) 0.04 and (D) $0.06 \mathrm{mg} / \mathrm{ml}$ for $24 \mathrm{~h}$ and compared with untreated cells. (E) Quantitative analysis demonstrated that the extract significantly induced apoptosis of human breast cancer cells in a concentration manner. ${ }^{\mathrm{P}} \mathrm{P}<0.05$ vs. control.

with increasing concentrations $(0.02,0.04$ and $0.06 \mathrm{mg} / \mathrm{ml})$ of the extract showed an increase in the ratio of apoptotic cells $(7.9,18.1$, and $33.2 \%$, respectively) for $24 \mathrm{~h}$. These data showed that the $P$. odoratum extract induced dose-dependent apoptosis in the cells.

Effect of P. odoratum extract on the protein expression levels of Bcl-2 and Bax. MDA-MB-231 cells were treated with the $0.1 \mathrm{mg} / \mathrm{ml} P$. odoratum extract for $0,6,16$, and $24 \mathrm{~h}$, and western blot analysis was used to investigate the effect on the protein expression levels of Bcl-2 and Bax. The results showed that, compared with the control group, there was a time-dependent decrease and increase in the protein expression levels of Bcl-2 and Bax, respectively (Fig. 4; $\mathrm{P}<0.05$ ). These findings indicate that the extract treatment resulted in downregulation of Bcl-2 and upregulation of Bax. $\beta$-actin expression was used as an internal control, and its level was not changed.
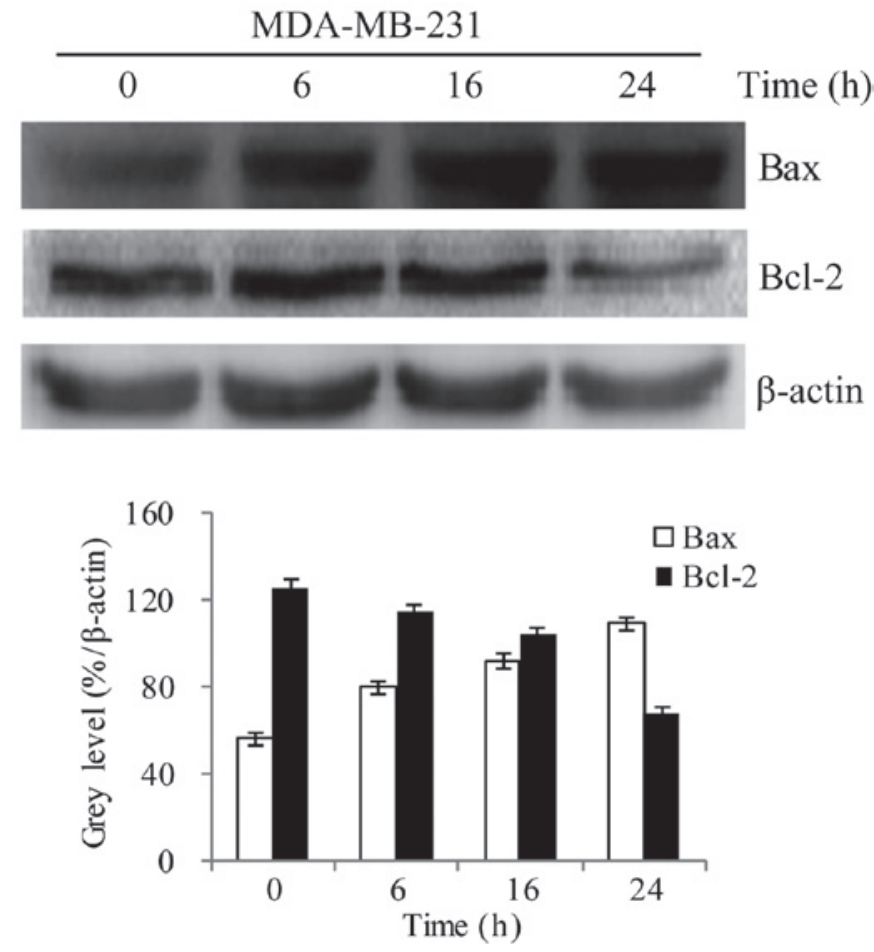

Figure 4. Effects of $0.1 \mathrm{mg} / \mathrm{ml}$ Polygonatum odoratum extract on the expression levels of Bcl-2 and Bax in MDA-MB-231 breast cancer cells after incubation for $0,6,16$ and $24 \mathrm{~h}$. Bcl-2, B-cell lymphoma 2; Bax, Bcl-2-associated $\mathrm{X}$ protein.

Determination of $\Delta \Psi m$ using $J C-1$. The $\Delta \Psi \mathrm{m}$ following JC-1 staining was also examined using fluorescence analysis. The results indicated that there was a significant change in the $\triangle \Psi \mathrm{m}$ loss in MDA-MB-231 cells following treatment with the $P$. odoratum extract $(0.1 \mathrm{mg} / \mathrm{ml}, 24 \mathrm{~h})$. As shown in Fig. 5, fluorescence conversion from red to green was observed in response to the extract treatment. This illustrates the early apoptosis that occurred in the cells subsequent to treatment. The intensity of the $\mathrm{JC}-1$ staining was measured using fluorescence microscopy. JC-1 passed across the membrane into the living cells and aggregated in the mitochondrial membrane, and the concentration of JC-1 increased as mitochondrial membrane potential increased. When the $\Delta \Psi \mathrm{m}$ is high, JC-1 accumulates in the mitochondrial matrix forming $\mathrm{J}$ aggregates and red fluorescence is produced. By contrast, when the $\Delta \Psi \mathrm{m}$ is low, JC-1 cannot accumulate in the mitochondrial matrix and the monomer with the green fluorescence is produced. Therefore, the $\Delta \Psi \mathrm{m}$ can be easily determined based on the fluorescent color change, and a decrease in $\Delta \Psi \mathrm{m}$ is a sign of early apoptosis. Change in fluorescence from red to green induced by JC-1 can easily be detected with the decline of the membrane potential. Therefore, JC-1 staining can be used as an index for the detection of early apoptosis.

\section{Discussion}

Recent research has been focusing on the search for novel antitumor drugs (36). The present study demonstrated that the $P$. odoratum extract inhibited the proliferation of the breast cancer MDA-MB-231 cell line, enhanced the expression of 

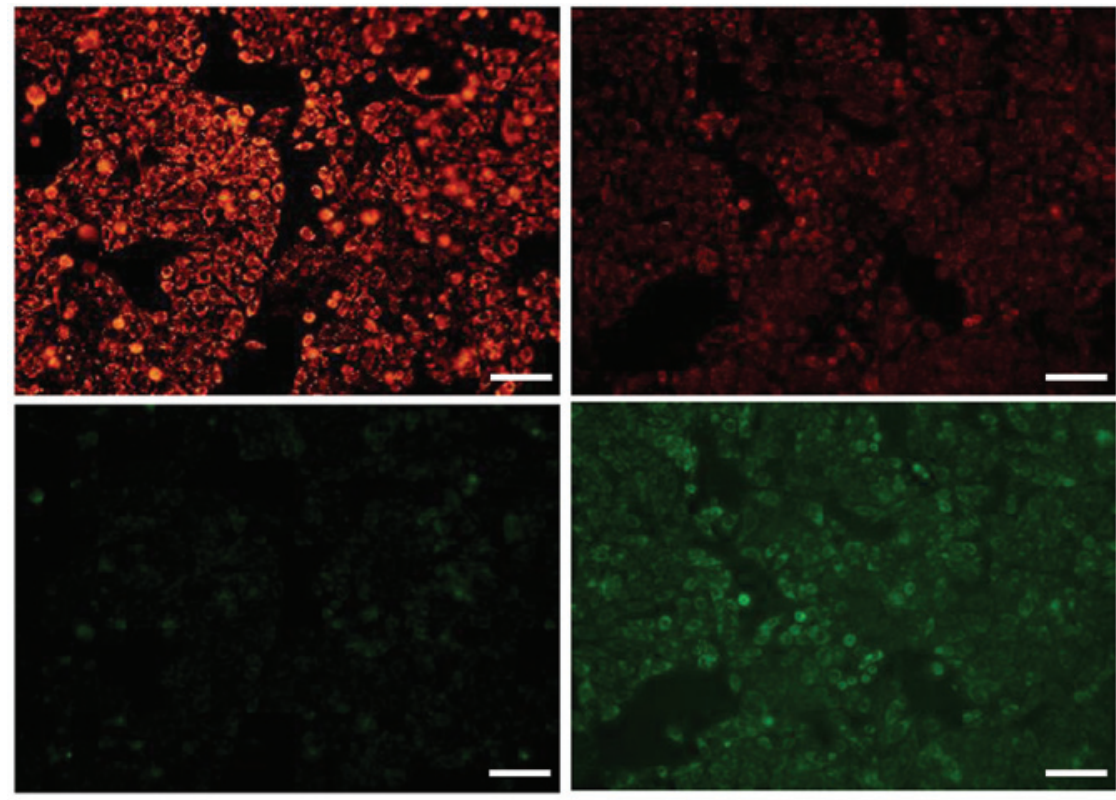

$0 \mathrm{mg} / \mathrm{ml}$

$0.1 \mathrm{mg} / \mathrm{ml}$

Polygonatum odoratum extract

Figure 5. Treatment with $0.1 \mathrm{mg} / \mathrm{ml}$ Polygonatum odoratum extract decreased the mitochondrial membrane potential in the MDA-MB-231 breast cancer cell line. Induction of apoptosis was observed in MDA-MB-231 breast cancer cells after $24 \mathrm{~h}$ of treatment (as observed by change in the fluorescence from red to green). Scale bar, $100 \mu \mathrm{m}$.

Bax, inhibited $\mathrm{Bcl}-2$ and reduced the $\Delta \Psi \mathrm{m}$, thereby resulting in MDA-MB-231 cell apoptosis.

Under physiological and pathological stimuli, normal cells undergo a spontaneous death process known as apoptosis. This process is active, highly ordered, signal-dependent, and controlled by genes and a series of enzymes. The initiation of the apoptotic process directly determines the 'fate' of the cell $(37,38)$. A high expression of the Bcl-2 gene maintains cell survival and has no effect on cell proliferation, as first demonstrated by Vaux et al in 1988 (39). The main physiological function of the Bcl-2 protein is inhibition of apoptosis, thereby prolonging the life of cells without any effect on cell differentiation (40). Furthermore, the expression of other genes of the Bcl-2 family serves an important role in the process of apoptosis, which includes mitochondrial regulation $(41,42)$. Numerous apoptotic cells exhibit enhanced expression of Bax, which is the most widely studied pro-apoptotic protein in the Bcl-2 family (43). Alsabeh et al (44) examined the expression of Bcl-2 in 371 cases of breast cancer, and identified a positive expression as high as $79.3 \%$, while a generally strong intensity of staining was observed, indicating that the $\mathrm{Bcl}-2$ test for the clinical diagnosis of breast cancer has a reference value. In the present study, expression levels of $\mathrm{Bcl}-2$ increased and Bax decreased, as compared with the original tissues. Bax/Bcl-2 downregulation exhibited significance. The present findings that the expression levels of Bax and Bcl-2 increased and decreased, respectively, may indicate that a mechanism that promotes various factors that induce tumor cell apoptosis.

$\mathrm{JC}-1$ is an ideal fluorescent probe and is widely used in the detection of $\Delta \Psi \mathrm{m}$ in purified cells or tissues (45). When the
$\Delta \Psi \mathrm{m}$ is high, JC-1 accumulates in the mitochondrial matrix forming J-aggregates and red fluorescence is produced (46). By contrast, when the $\Delta \Psi \mathrm{m}$ is low, JC-1 cannot accumulate in the mitochondrial matrix and the monomer with the green fluorescence is produced (47-49). Therefore, the $\Delta \Psi \mathrm{m}$ can be easily determined based on the fluorescent color change, and a decrease in $\Delta \Psi \mathrm{m}$ is a sign of early apoptosis (50). Change in fluorescence from red to green induced by JC-1 can easily be detected with the decline of the membrane potential. Thus, JC-1 staining can be used as an index for the detection of early apoptosis. In the present study, red fluorescence intensity was attenuated, whereas the intensity of green fluorescence enhanced. These findings indicated that the mitochondrial membrane potential declined and apoptosis was activated.

In conclusion, the present study revealed that the $P$. odoratum extract inhibited the proliferation and induces the apoptosis of human breast cancer MDA-MB-231 cells. This treatment was also found to affect the expression of apoptosis-associated proteins. These results suggest that the $P$. odoratum extract may have certain value in the treatment of breast cancer. However, the molecular mechanism involved in the extracts' effects requires further elucidation. Furthermore, toxicological and in vivo experiments are also necessary to confirm the findings of the present study.

\section{Acknowledgements}

The present study was supported by grants from the National Natural Science Foundation of China (nos. 81000992 and 81372899), the Natural Science Foundation of Anhui Province (no. 1508085MH166) and the National Training Programs 
of Innovation and Entrepreneurship for Undergraduates (no. 201310367037).

\section{References}

1. Ferlay J, Shin HR, Bray F, Forman D, Mathers C and Parkin DM: Estimates of worldwide burden of cancer in 2008: GLOBOCAN 2008. Int J Cancer 127: 2893-2917, 2010.

2. Kim SH, Son BH, Hwang SY, Han W, Yang JH, Lee S and Yun YH: Fatigue and depression in disease-free breast cancer survivors: prevalence, correlates, and association with quality of life. J Pain Symptom Manage 35: 644-655, 2008.

3. Fann JR, Thomas-Rich AM, Katon WJ, Cowley D, Pepping M, McGregor BA and Gralow J: Major depression after breast cancer: A review of epidemiology and treatment. Gen Hosp Paychiatry 30: 122-126, 2008.

4. Karakoyun-Celik O, Gorken I, Sahin S, Orcin E, Alanyali H and Kinay M: Depression and anxiety levels in woman under follow-up for breast cancer: Relationship to coping with cancer and quality of life. Med Oncol 27: 108-113, 2010.

5. Xu LX, Shen SS, He JJ, Fu Y, Xue XD, Liang Y, Lin Y, Zhang XH and He JC. Relationship among anxiety, depression, well-being index and social support in breast cancer patients. Zhong Guo Xin Li Wei Sheng Za Zhi 27: 473-478, 2013.

6. DeSantis C, Ma J, Bryan L and Jemal A: Breast cancer statistics, 2013. CA Cancer J Clin 64: 52-62, 2014.

7. Ferlay J, Soerjomataram I, Dikshit R, Eser S, Mather C, Rebelo M, Parkin DM, Forman D, Bray F: Cancer incidence and mortality worldwide: sources, methods and major patterns in GLOBOCAN 2012. Int J Cancer 136: E359-E386, 2015.

8. Green J, Cairns BJ, Casabonne D, Wright FL, Reeves G and Beral V; Million Women Study collaborators: Height and cancer incidence in the Million Women Study: prospective cohort, and meta-analysis of prospective studies of height and total cancer risk. Lancet Oncol 12: 785-794, 2011

9. Mellemkjaer L, Christensen J, Frederiksen K, Baker JL, Olsen A, Sørensen TI and Tjønneland A: Leg length, sitting height and postmenopausal breast cancer risk. Br J Cancer 107: 165-168. 2012.

10. Ritte R, Lukanova A, Tjonneland A, Olsen A, Overvad K, Mesrine S, Fagherazzi G, Dossus L, Teucher B, Steindorf K, et al: Height, age at menarche and risk of hormone receptor-positive and -negative breast cancer: A cohort study. Int J Cancer 132: 2619-2629, 2013

11. Kabat GC, Kim MY, Hollenbeck AR and Rohan TE: Attained height, sex, and risk of cancer at different anatomic sites in the NIH-AARP Diet and Health Study. Cancer Causes Control 25: 1697-1706, 2014.

12. Ni ZJ, Wang HS and Chen YX: The trend analysis of mortality with female breast cancer during 1989-2008, Haimen city. Jiang Su Yu Fang Yi Xue 20: 1-3, 2009 (In Chinese)

13. Pan XD, Wang HW and Li X: Breast cancer mortality tendency among women from 1992 to 2006 in Shenyang. Zhong Guo Fu You Bao Jian 23: 4703-4705, 2008 (In Chinese).

14. Wang Y, Ma Q, Li HQ, Diao YT, Yin C, Ciu YC, Xu AQ, Ma JQ and Guo XL: Changing trend of female breast cancer mortality in Shandong province, 1970-2005. Zhong Hua Zhong Liu Fang Zhi Za Zhi She 16: 729-732, 2009 (In Chinese).

15. Liang YQ: Analysis of female breast cancer mortality in Nanjing in 1997-2005. Zhi Ye Yu Jian Kang 23: 357-358, 2007 (In Chinese).

16. Blichert-Toft M, Nielsen M, During M, Møller S, Rank F, Overgaard M and Mouridsen HT: Long-term results of breast conserving surgery vs. mastectomy for early stage invasive breast cancer: 20-year follow-up of the Danish randomized DBCG-82TM protocol. Acta Oncol 47: 672-681, 2008.

17. Goldhirsch A, Wood WC, Gelber RD, Coates AS, Thürlimann B and Senn HJ; 10th St. Gallen conference: Progress and promise: Highlights of the international expert consensus on the primary therapy of early breast cancer 2007. Ann Oncol 18: 1133-1144, 2007.

18. Ahunbay EE, Robbins J, Christian R, Godley A, White J and Li XA: Interfractional target variations for partial breast irradiation. Int J Radiat Oncol Biol Phys 82: 1594-1604, 2012.

19. Yamashiro H and Toi M: Molecular targeted therapy for breast cancer treatment, challenge to cure. Nihon Rinsho 68: 1854-1858, 2010 (In Japanese).

20. Chen SS and Yu ZH: Recent research on traditional Chinese medicine in the treatment of breast cancer. Modern Oncology 23: 2072-2077, 2015.
21. Kim J, Han JY, Shaw B, McTavish F and Gustafson D: The roles of social support and coping strategies in predicting breast cancer patients' emotional well-being: Testing mediation and moderation models. J Health Psychol 15: 543-552, 2010.

22. Li J, Huang XY, Zou XZ, Wei W and Wang ZX: Clinical curative effect of traditional Chinese medicine, western medicine Fuzheng attack comprehensive treatment of malignant tumor. Zhong Guo Yi Yao Dao Kan 3: 529-530, 2014 (In Chinese).

23. Chen YE, Wang SP, Hu YY, Chen MW and Wang YT: Research in novel drug delivery system of anti-tumor Chinese medicine (part three) - Fuzheng guben Chinese medicine. Shi Jie Ke Xue Ji Shu-Zhong Yi Yao Xian Dai Hua 2: 201-206, 2013 (In Chinese).

24. Commission of Pharmacopoeia. Chinese Pharmacopoeia: Part One. China Medical Science and Technology Press, Beijing, 2010.

25. Zhijun He: A summary on 42 cases of type 2 diabetes treated by Gegeng Danshen Yuzhu decoction. Hu Nan Zhong Yi Za Zhi 24: 10-11, 2008.

26. Shu XS, Lv JH, Tao J, Li GM, Li HD and Ma N: Antihyperglycemice effects of total flavonoids from Polygonatum odoratum in STZ and alloxan-induced diabetic rats. J Ethnopharmacol 124: 539-543, 2009.

27. Yang HJ, Yang SH, Zhang HT, Ma L and Zhang LC: Polygonatum odoratum chemical composition, pharmacological effects research progress and the present situation of the development and utilization. Ren Shen Yan Jiu 3: 40-45, 2012 (In Chinese).

28. Li CY, Pan XY, Zhang MC and Liu H: The antineoplastic mechanism of the extract B of Polygonatum odoratum. Zhong Guo Mian Yi Xue Za Zhi 4: 253-254, 2003 (In Chinese).

29. Zhang H, Chen L, Kou JP, Zhu DN, Qi J and Yu BY: Steroidal sapogenins and glycosides from the fibrous roots of Polygonatum odoratum with inhibitory effect on tissue factor (TF) procoagulant activity. Steroids 89: 1, 2014.

30. Deng Y, He K, Ye X, Chen X, Huang J, Li X, Yuan L, Jin Y, Jin Q and Li P: Saponin rich fractions from Polygonatum odoratum (Mill.) Druce with more potential hypoglycemic effects. J Ethnopharmacol 141:228-233, 2012.

31. Park S, Hong SM, Ahn IS, Kim YJ and Lee JB: Huang-Lian-Jie-Du-Tang supplemented with Schisandra chinensis Baill. and Polygonatum odoratum Druce improved glucose tolerance by potentiating insulinotropic actions in islets in $90 \%$ pancreatectomized diabetic rats. Biosci Biotechnol Biochem 73(: 2384-2392, 2009.

32. Park S, Hong SM, Ahn IS, Kim YJ and Lee JB: Huang-Lian-Jie-Du-Tang supplemented with Schisandra chinensis Baill. and Polygonatum odoratum Druce improved glucose tolerance by potentiating insulinotropic actions in islets in $90 \%$ pancreatectomized diabetic rats. Biosci Biotechnol Biochem 73: 2384-2392, 2009.

33. Yang Y, Xu HL, Zhang ZT, Liu JJ, Li WW, Ming H and Bao JK: Characterization, molecular cloning, and in silico analysis of a novel mannose-binding lectin from Polygonatum odoratum (Mill.) with anti-HSV-II and apoptosis-inducing activities. Phytomedicine 18: 748-755, 2011.

34. Ouyang L, Chen Y, Wang XY, Lu RF, Zhang SY, Tian M, Xie T, Liu B and He G: Polygonatum odoratum lectin induces apoptosis and autophagy via targeting EGFR-mediated Ras-Raf-MEK-ERK pathway in human MCF-7 breast cancer cells. Phytomedicine 21:1658-1665, 2014.

35. Rafi MM and Vastano BC: Identification of a structure specific Bcl-2 phosphorylating homoisoflavone molecule from Vietnamese coriander (Polygonatum odoratume) that induces apoptosis and G2/M cell cycle arrest in breast cancer cell lines. Food Chem 104: 332-340, 2007.

36. Yang H, Huang WR and Yu L: Clinical application and research process of novel antitumor drug. J New Med 19: 480-485, 2010.

37. Vaux DL: Apoptosis timeline. Cell Death Differ 9: 349-354, 2002.

38. Edinger AL and Thompson CB: Death by design: Apoptosis, necrosis and autophagy. Curr Opin Cell Biol 16: 663-669, 2004.

39. Vaux DL, Cory S and Adams JM: Bcl-2 gene promotes haemopoietic cell survival and cooperates with c-myc to immortalize pre-B cells. Nature 335: 440-442, 1988.

40. Wang T, Liu CZ, Liu YZ, Yu JC and Han JX: Research progress of $\mathrm{Bcl}-2 / \mathrm{Bax}$ gene regulated mechanism for organism cell apoptosis. Zhong Guo Lao Nian Xue Za Zhi 16: 1658-1660, 2008 (In Chinese). 
41. Li $\mathrm{M}$ and Lin $\mathrm{J}$ : The apoptotic pathways and their mechanisms. Guo Ji Fu Chan Ke Xue Za Zhi 2: 103-107, 2014 (In Chinese).

42. Xu RR and Li YD: Research progress of Bcl-2 families interact with mitochondrial apoptosis pathway. Zhong Guo Lao Nian Xue Za Zhi 12: 2977-2979, 2013 (In Chinese).

43. Oltvai ZN, Milliman CL and Korsmeyer SJ: Bcl-2 heterodimerizes in vivo with a conserved homolog, Bax, that accelerates programmed cell death. Cell 74: 609-619, 1993.

44. Alsabeh R, Wilson CS, Ahn CW, Vasef MA and Battifora $\mathrm{H}$ : Expression of Bcl-2 by breast cancer: A possible diagnostic application. Mod Pathol 9: 439-444, 1996.

45. Garner DL, Thomas CA, Joerg HW, DeJarnette JM and Marshall CE: Fluorometric assessments of mitochondrial function and viability in cryopreserved bovine spermaotozoa. Biol Reprod 57: 1401-1406, 1997.
46. Castedo M, Ferri K, Roumier T, Métivier D, Zamzami N and Kroemer G: Quantitation of mitochondrial alterations associated with apoptosis. J Immunol Methods 265: 39-47, 2002.

47. Baxa DM, Luo X and Yoshimura FK: Genistein induces apoptosis in T lymphoma cells via mitochondrial damage. Nutr Cancer 51: 93-101, 2005.

48. Tan YC, Chen ZJ, Lu SM and Gao X: Detection of mitochondrial membrane potential changes in spermatozoa by fluorescent dyes JC-1. Shan Dong Da Xue Xue Bao 5: 447-450, 2006 (In Chinese).

49. Xia XY, Wu YM, Hou BS, Yang B, Pan LJ, Shi YC, Jin BF, Shao Y, Cui YX and Huang YF: Evaluation of sperm mitochondrial membrane potential by JC-1 fluorescent staining and flow cytometry. Zhonghua Nan Ke Xue 14: 135-138, 2008 (In Chinese).

50. Wang L, Yao SM and Wang Q: The mechanism of mitochondrial impairment induced by cadmium. Huan Jing Yu Zhi Ye Yi Xue 23: 73-75, 2006 (In Chinese). 